\title{
Inhibition of Partially Purified Sorbitol Dehydrogenase Activity From Sera of Patients With Type I Diabetes
}

\author{
Nashwan I. Abo \\ Department of Chemistry / College of Education \\ University of Mosul
}

Received

$22 / 12 / 2008$
Accepted

07 / 06 / 2009

\section{|ld}

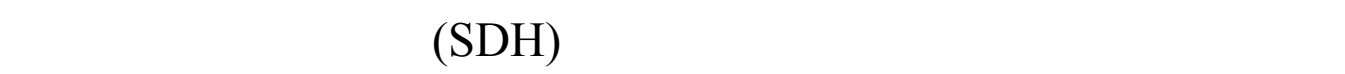

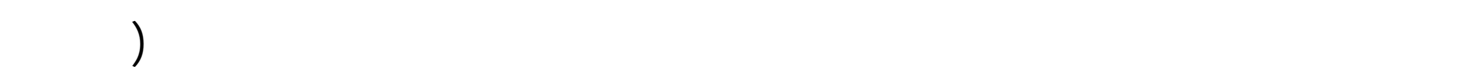

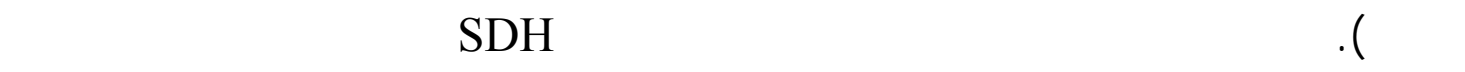

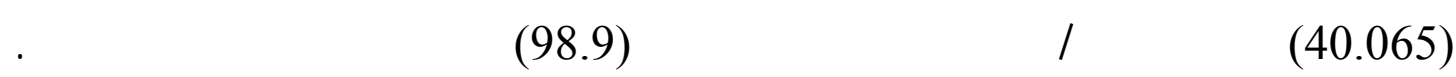
دسس تشبط انزيم SDH المقق بوجود عقاري الكليبينكيمايد والروزكليتازون، وتبين ان أعلى

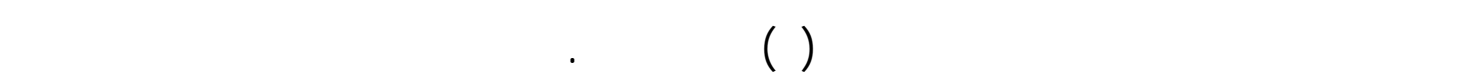

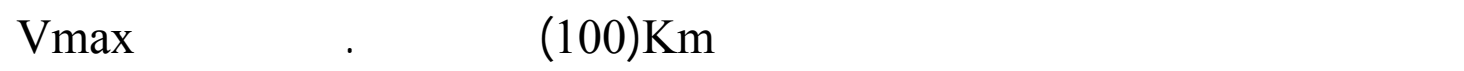

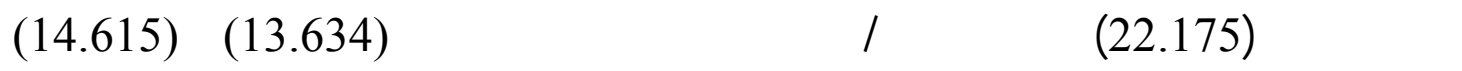

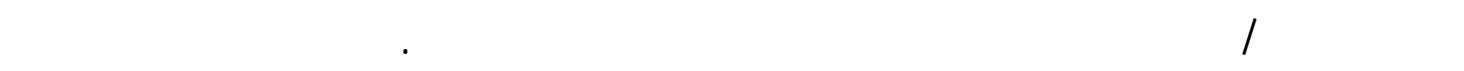

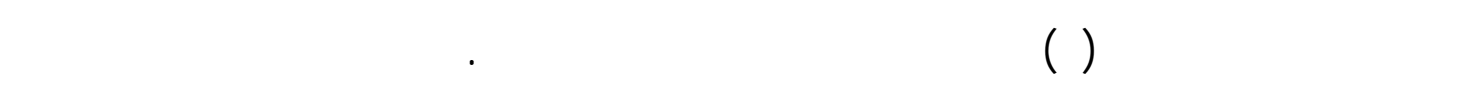
هنين العقارين يمكن ان يسهم في تقليل مضاعفلت مرضى اللسكر النوع الأول من خلال تشيط الفيط SDH الكلملت الفتلحية:سوربيتول ديهايدروجينيز، مسار بوليول، داء اللسكرل

\section{Abstract}

In this research Sorbitol dehydrogenase (SDH) was partially purified from sera of patients with type I diabetes mellitus by dialysis and ion exchange chromatography step by step. One peak of SDH activity was obtained with specific activity of $40.065 \mathrm{unit} / \mathrm{mg}$ protein and with purification fold of 98.9 compared to crud enzyme. Inhibition of SDH 
was studied by Glibenclamide and Rosiglitazone drugs, the best concentration of both inhibiters was $6 \mathrm{mM}$. The mechanism of SDH inhibition by using both drugs were noncompetitive. There is no change in $\mathrm{Km}$ value $100 \mathrm{mM}$. Vmax value without inhibitor was 22.175 but 13.634 and 14.615 unit $/ \mathrm{ml}$ with Glibenclamide and Rosiglitazone respectively. Accordingly, the inhibition constant Ki was calculated and appeared $7 \mathrm{mM}$ for both inhibitors above.

Finally, we propose that action of these drugs may contribute to decrease patients with type I diabetes complications through inhibition SDH which plays an important role in polyol pathway.

Key words: Sorbitol dehydrogenase, polyol pathway, diabetes.

\section{Introduction}

Diabetes mellitus is a heterogeneous metabolic disorder characterized hyperglycemia resulting from defective insulin secretion, resistance to insulin action or both(1). Type I diabetes mellitus is the consequence of an autoimmune-toward pancreatic- $\beta$-cells leading to insulin deficiency (2).

The major metabolic changes caused by hyperglycemia are increased glucose influx into the polyol pathway, elevated formation of oxygen-free radicals(3). The polyol pathway synthesizes fructose from glucose in a series of passages. In the first of these, the enzyme aldos reductase reduced glucose to sugar alchohol sorbitol using NADPH as a cofactor (4), the increased glucose concentration is associated with the increase of polyol pathway activity(5).

Sorbitol dehydrogenase (SDH) E.C(1.1.1.14) is a member of the superfamily of medium-chain dehydrogenases/reductases. SDH, the second enzyme in the polyol pathway, oxidizes sorbitol to fructose in the presence of $\mathrm{NAD}^{+}$and the enzyme SDH is considered an important part in this pathway. As a member of the alchohol dehydrogenase super family $(6,7)$. High levels of SDH activity lead to increasing fructose availability(8) which plays an important role in the pathogenesis of diabetic complications (6).

Recent studies show that SDH activity was increased during chronic ischemia and diabetes. Inhibition of SDH which plays an important role in reducing ischemic was associated with lower cytosolic $\mathrm{NADH} / \mathrm{NAD}^{+}$and with increased glucose uptake and oxidation (7).

At least increasing action of this pathway lead to many metabolism complication such as depletion of NADPH that it is very necessary to regeneration of antioxidant reduced glutathione (4), retinopathy (8), effect of the nervous system and especially brain cells and increase oxidative stress $(10)$.

The aim of this study is inhibition of SDH activity (by Glibenclamide and Rosiglitazone drugs) which plays an important role in polyol pathway. 


\section{Materials and Methods}

Collection of samples: Venous blood samples were drawn from Patients with diabetes mellitus type I from Ibn-sina hospital -Mosul city-and by arrange (2-3) milliliter to one sample.

Blood serum isolation:- The serum is isolated by putting tubes in a water bath $(37)^{\circ} \mathrm{C}$ for $(10) \mathrm{min}$, and centrifuged at $1008 \mathrm{xg}$ for $(10) \mathrm{min}$, the supernatant was taken to conserve in freezing(11).

Determination of protein: Biuret method was used to determine total protein concentration(12).

Sorbitol dehydrogenase assay:- Sorbitol dehydrogenase (SDH) was assayed by method of Ulrich(13). Increasing absorbance was measured spectrophotometrically by monitoring intervals for (5)min at (365)nm in the presence of $\mathrm{NAD}^{+}$as a cofactor.

Dialysis:- Seven milliliter of serum was dialyzed for about (5) hours against (0.2)M of triethanolamin buffer solution $\mathrm{pH}=7.4$ at $(4)^{\circ} \mathrm{C} .(14)$

Fractionation on DEAE-Cellulose column:- The dialyzed enzyme solution was applied on DEAE-cellulose anion exchanger column $(2.5 \times 40) \mathrm{cm}$, which has been equilibrated with step by step buffer at $(50,100,150,200) \mathrm{mM}$ of $\mathrm{pH}=7.4$. fractions of (6)ml volume were collected. Flow rate was approximately $72 \mathrm{ml} / \mathrm{hr}$.

Inhibition of SDH:- SDH activity was inhibited by addition $(0.2) \mathrm{ml}$ of inhibitor $(6 \mathrm{mM})$ to $(0.2) \mathrm{ml}$ of enzyme solution $(5 \mathrm{mg} / \mathrm{ml})$.

\section{Results and discussion}

Table (1) shows purification steps of SDH (step by step) $(50,100$, $150,200) \mathrm{mM}$ of $\mathrm{pH}=7.4$. The specific activity of crud enzyme was (0.405)unit /mg protein, after dialysis become (0.676)unit/mg protein.

Table (1): SDH purification steps from serum patients with type I diabetes

\begin{tabular}{|c|c|c|c|c|c|c|c|c|}
\hline $\begin{array}{l}\text { Purification } \\
\text { steps }\end{array}$ & $\begin{array}{l}\text { Volume } \\
\text { (ml) }\end{array}$ & $\begin{array}{c}\text { Protein } \\
\text { concentration } \\
(\mathrm{mg} / \mathrm{ml})\end{array}$ & $\begin{array}{c}\text { Total } \\
\text { protein }(\mathrm{mg})\end{array}$ & $\begin{array}{c}\text { Activity } \\
(\mathrm{U} / \mathrm{ml})\end{array}$ & $\begin{array}{c}\text { Total } \\
\text { activity } U^{*}\end{array}$ & $\begin{array}{l}\text { Specific } \\
\text { activity } \\
\text { (U/mg--) }\end{array}$ & Yield \% & $\begin{array}{l}\text { Purification } \\
\text { fold }\end{array}$ \\
\hline Crude & 6 & 47.625 & 285.75 & 19.292 & 115.75 & 0.405 & 100 & 1 \\
\hline Dialysis & 5.7 & 45.6 & 259.92 & 30.868 & 175.94 & 0.676 & 152 & 1.66 \\
\hline $\begin{array}{c}\text { Ionexchang } \\
\text { DEAE- } \\
\text { Cellulose } \\
\text { peak }\end{array}$ & 78 & 2.36 & 184.08 & 94.533 & 7373.57 & 40.056 & 6370.2 & 98.90 \\
\hline
\end{tabular}

* U: A unit is defined as the amount of enzyme that catalyzed the reduction of $1 \mu \mathrm{Mol}$ of $\mathrm{NAD}^{+}$per minute.

We obtained one peak of SDH activity showing in Figure(1) 


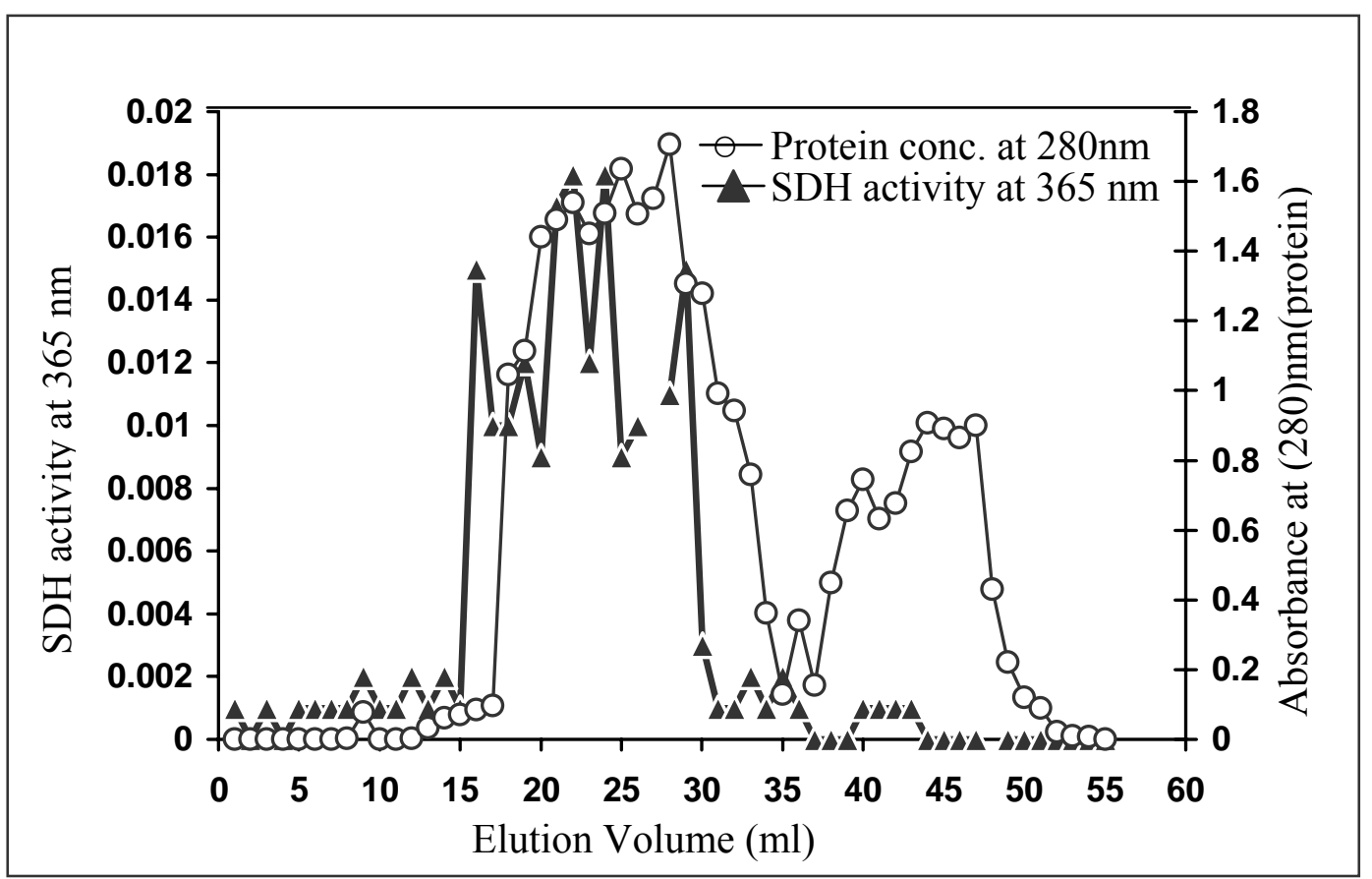

Figure(1): Elution profile of purified SDH by ion exchange chromatography

\section{Inhibition of SDH activity:}

SDH activity was inhibited by Glibenclamide and Rosiglitazone drugs with concentrations (1-10)mM .

Table(2) show the concentration of both drugs that exhibited maximal inhibitory effect was (6)mM, and the percentage inhibition was (97.9\%)

Table (2): the percentage inhibition of SDH activity by Glibenclamide and Rosiglitazone

\begin{tabular}{|c|c|c|c|}
\hline $\begin{array}{c}\text { Glibenclamide } \\
{[\mathrm{mM}]}\end{array}$ & \% inhibition & $\begin{array}{c}\text { Rosiglitazone } \\
{[\mathrm{mM}]}\end{array}$ & $\%$ inhibition \\
\hline 1 & $9 \mu, \wedge$ & 1 & 95.9 \\
\hline 2 & 93.8 & 2 & 89.7 \\
\hline 3 & 95.9 & 3 & 85.7 \\
\hline 4 & 95.9 & 4 & 77.5 \\
\hline 5 & $9 \mu, \wedge$ & 5 & 34.69 \\
\hline 6 & 97.9 & 6 & 97.9 \\
\hline 7 & 89.7 & 7 & 95.9 \\
\hline 8 & 53.6 & 8 & 85.71 \\
\hline 9 & 7.5 & 9 & 89.7 \\
\hline 10 & 55.1 & 10 & 91.8 \\
\hline
\end{tabular}


Glibenclamide also known as a glyburid (USAN), is an antidiabetic drug in a class of medication known as sulfonylurea, widely used to treatment patient with type II diabetes (15). Thiazlidinediones are a new oral anti diabetic drugs that directly target insulin resistance (16), Rosiglitazon is one of this family which is used to treat adult-onset type II diabetes(17).

Polyol pathway is an important role in pathogenesis of diabetic neuropathy by dependant of biochemical pathways(18), and the development of diabetes complications (19). The SDH enzyme is one of this pathways member(7), SDH activity was significantly increased in patients with type I diabetes(10).

In this study we observed that some drugs which is given to the patients with diabetes type II can be inhibiting SDH. Lineweaver-Burk plot was noncompetitive inhibition by using Glibenclamide and Rosiglitazone drugs, Vmax without inhibitor was (22.175)unit $/ \mathrm{ml}$, whereas Vmax was (13.634), (14.615)unit/ml with both inhibitors respectively, figure(2) and (3).

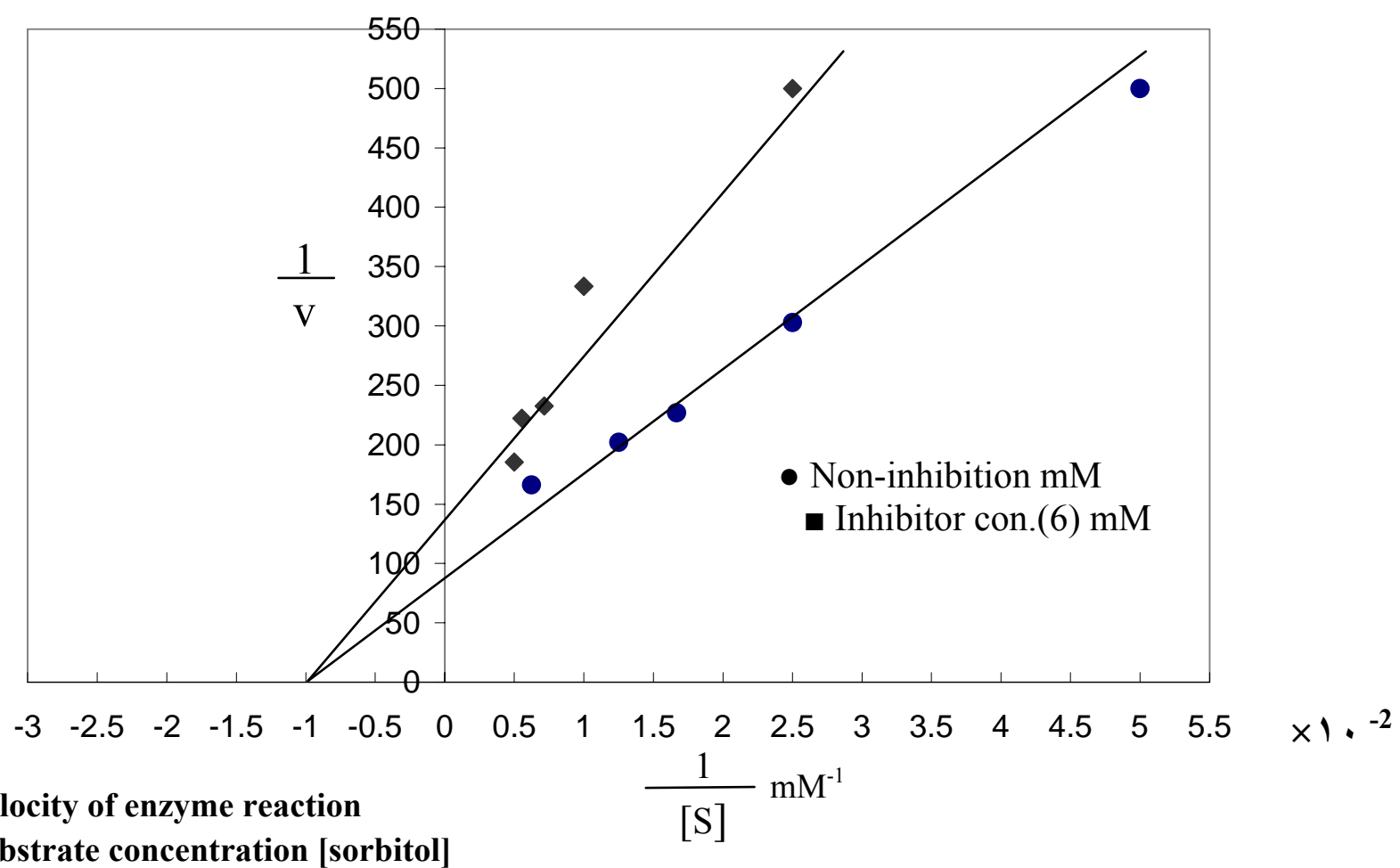

Figure (2): Lineweaver-Burk plot shows inhibition type by Glibenclamide on purified SDH activity 


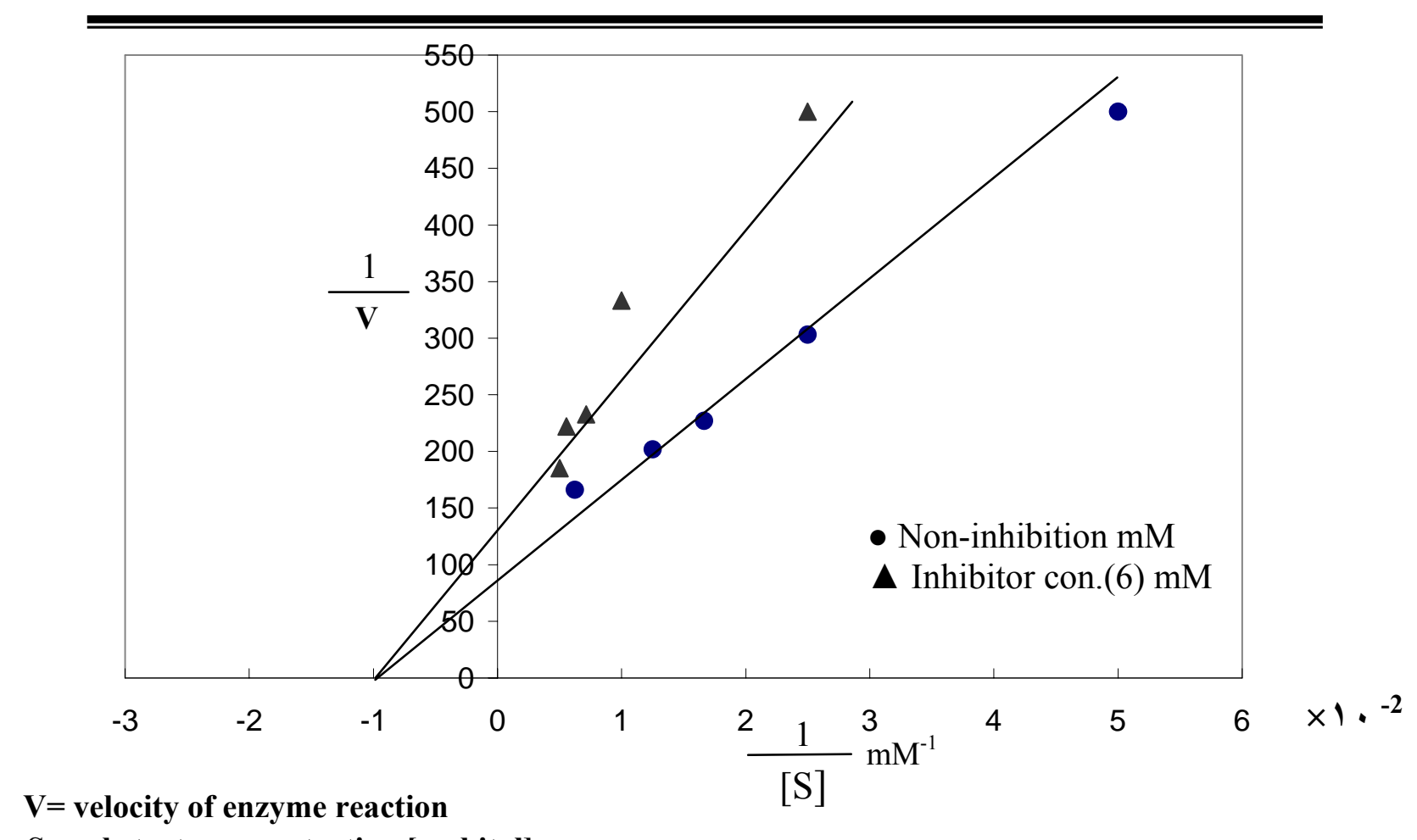

$\mathrm{S}=$ substrate concentration [sorbitol]

Figure (3): Lineweaver-Burk plot shows inhibition type by Rosiglitasone on purified SDH activity

$\mathrm{Km}$ value is invariable (100)mM. The inhibition constants (Ki) value was (7) $\mathrm{mM}$ for both inhibitor.

Inhibition of SDH can be reduced metabolic abnormalities(20), some studies indicated that SDH was inhibition by sorbitol competitive 1-thiosorbitol(21), and several inhibitors provide competitive inactivation by DL-2-bromo-3-(5-imidazolyl) propionic acid(22).

Finally, we obtained that the two inhibitors have a similar inhibiting properties on SDH activity. Whereas these inhibitors have the same structure which contains terminal active oxygen and sulfur atoms.

Inhibitory effect of aliphatic thiols (L-theritol and DL-1-phenyl-2ethandiol) and aromatic (1-thio-1-phenylmethane and 1-thio-2phenylethane) that responsible of interaction with an enzymatic hydrophobic site is important for inhibitor binding (21), and this thiole are generally the most strong inhibitor of enzyme (22). In this study the two inhibitor contain sulfur atom in its structure, there; may these atoms react with hydrophobic active site on SDH.

\section{References}

1) Gravin J.R., Albert K.C.M.M., Davidson M.B., Defromzo R.K., Drash A., Gabbe S.G., Genuth S., Harris M.I., Kahn R. and Keen H . Diab.Care. 20:1183-1197.(1997). 
2) Ahmed R.G. Medical. J. Islam World. Academy Sciences. 15:1,3142. (2005).

3) Latha M. and Paril L. Brazil. J. of Medi and Biol. Research. 37. 577586. (2004)

4) Piconi L. and Cerillo A. Clin. Scie. Resea. Institute. 36-38. (2007).

5) Ibrahime S.S. and Rizk S.M. Afric. J. of Biochem. Rese. 2(8), pp.174-180.(2008).

6) Hoshi A., Takahashi M., Fijii J., Myint T., Kanito H Suzuki K., Yamasaki Y., Kamada T. and Taniguchi N. Biochem. J. 318, 119123.(1996).

7) Hwang Y.C., Baker S., Ellery C.A., Oates P.G and Ramasamy R. FASEB. J.17. 2331-2333.( 2003).

8) Brownlee M.Diab Care 15, 1835-1843.(1992).

9) Miwa K., Nakamora J., Nakashima E. and Kato Koichi. J. Inform. 6, 1-9.(2002).

10) Yang B., Hodgkison A.D., Oates P.J., Kwon H.M., millward B.A and Demaine A.G. Diab. 55. 1450-1455.(2006).

11) Zhang D.J., Eiswik R.R., Miller G. and Bialy J. L. Clin. Chem., 44: 1325.(1998).

12) Wootton I.D.P. "Microanalysis in medical biochemistry". $5^{\text {th }}$ ed., Churchill Livingstone, Edinburgh, pp.156-159.(1974).

13) Ulrich H.B.. "Methods of enzymatic analysis" $2^{\text {nd }}$ English edition verlag Cheme Weinhem. Acadimic press.Inc. New York. Sanfrancisco and London . 569-573.( (1974).

14) Robyt F.J. and White J.B. "Biochemical techniques, theory and practice". Brookes Cole publishing company, Monterey, California, p.263(1987).

15) World Health Organization "Model list of essential medicines. WHO. p. 21. (2007).

16) Bedir A., Aliyazicicoglu Y., Kahraman H., Yurdakul Z., Uysal M., Suvaci D. E., OkuyucuA., Hokelek M. and Alvyr M. Enviro. and Molec. Mutagenesis. Vol. 47:718-724.(2006).

17) Day C. Diab. Med. 16:179-192.(1999).

18) Shmidt R.E., Dorsey D.A., Beaudet L.N., Plurad S.B., Williamson J.R. and Ido Y. J. Nuropath. experimn. Neuology. 57 (12):1175-89. (1998).

19) Dunlop M..Kidney.Int. supp. 77. S3-S12 .(2000).

20) Obosova I.G., Fathallah L., Lang H.J. and Green D.A. Diabetologia. 42: 1187-94.(1999).

21) Lindstad R.I. and Mckinley-Mckee J.S. Eur. J. Biochem. 1; 241(1):142-8. (1996).

22) Lindstad R.I., Hermansen L.F. and McKinley-McKee J.S. Eur. J. Biochem. 221(2). 847-854. (2005). 